\title{
THE LINGUISTIC REPRESENTATION OF MOLUCCAS RIOTS IN AMBON'S LOCAL NEWSPAPER (SIWALIMA)
}

\author{
Michele Hitijahubessy ${ }^{\mathrm{a}}$, Nurul Chojimah ${ }^{\mathrm{b}}$, Esti Junining ${ }^{\mathrm{c}}$ \\ ${ }^{a}$ Faculty of Cultural Studies, Universitas Brawijaya

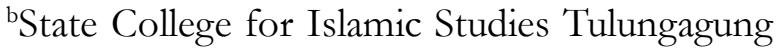 \\ ${ }^{\mathrm{c}}$ Faculty of Cutural Studies, Universitas Brawijaya \\ e-mail: michele.hiti@gmail.com
}

\begin{abstract}
Abstrak
Kerusuban di Maluku adalah salah satu konflik terbesar di Indonesia yang terjadi pada 2000-2002, tak heran insiden itu menjadi perhatian banyak pihak, terutama media massa. Namun, media massa juga tidak bebas dari bias karena ada ideologi yang dapat memengarubi konten berita. Untuk alasan ini, para peneliti melakukan penelitian tentang representasi kerusuban Maluku di Siwalima. Fokus penelitian ini adalah, bagaimana representasi linguistik kerusuban Maluku di Siwalima? Tujuan dari penelitian ini adalah untuk menyelidiki representasi linguistik dari kerusuban Maluku di Siwalima. Penelitian ini menggunakan metode kualitatif dengan model Fairclough's (1995) Critical Discourse Analysis untuk membantu proses analisis data. Data yang digunakan adalab representasi linguistik kerusuban Maluku di Siwalima. Para peneliti menemukan babwa representasi linguistik dari kerusuban Maluku di Siwalima lebih menyoroti tentang ketidakmampuan pemerintah dan militer dalam menangani konflik. Oleh karena itu, militer dianggap hanya mendukung satu kelompok tertentu, babkan ikut serta dalam memperluas konflik dan menjadikan penduduk asli Maluku sebagai korban konflik. Kondisi Maluku saat itu juga direpresentasikan sebagai peristiwa yang suram.
\end{abstract}

Kata kunci: analisis wacana kritis, Siwalima, kerusuban Maluku, representasi linguistik

\begin{abstract}
Riots in Moluccas were one of the biggest conflicts in Indonesia that occurred in 2000-2002, no wonder the incident was a concern of many parties, especially the mass media. However, the mass media is also not free from bias because there are ideologies that can affect the content of the news. For this reason, researchers conducted a study on the representation of the Moluccas riots in Siwalima. The focus of this research is, how was the linguistic representation of the Moluccas riots in Siwalima? The objective of the study was to investigate the linguistic representation of Moluccas riots in Siwalima.This study used a qualitative method with Fairclough's (1995) model of Critical Discourse Analysis to help on the process of data analysis. The data used was linguistic representation of Moluccas riots in Siwalima. The researchers found that the linguistic representation of the Moluccas riots in Siwalima highlights more about the incompetence of the government and the military in dealing with the conflict. Hence, the military was considered to have favored only one particular group, even participated in extending the conflict and making native Moluccan victims of the conflict. The condition of Moluccas at that time was also represented as a gloomy event.
\end{abstract}

Keywords: critical discourse analysis, siwalima, moluccas riots, linguistic representation 


\section{INTRODUCTION}

The "Maluku riots" were generally recognized in most "stories" as having been a private quarrel between an Ambon bus driver and Bugis passenger in Ambon 1999, which was rapidly spreading in both religions: Muslims and Christians. After several days of destructive unrest in the city, sectarian conflict spread rapidly throughout the islands of Ambon and Central Maluku, triggering further conflict in Aru, Kei, North Maluku, Tanimbar, Buru and even as far as Lombok (Goss, 2000).

During the Moluccas riots, hundreds of Mosques and Churches were destroyed. It is estimated that over 10,000 people had killed and over half a million rendered homeless (Sholeh, 2008). This riot became one of the biggest phenomena that ever happened in Indonesia. The condition was captured and exposed by many parties; one of them is the newspaper. In addition, although the press around the world claims factuality, objectivity, and neutrality in news reporting, news reports must be influenced by culture, ideology, and social layer. The news actually also not only reports the matters but reflects the attitude of journalists towards events, thus making the news unable to be reported in a fully neutral manner.

,Furthermore, because there is no fully neutral news, then in the delivery of the news also contains the attitude and ideology of the journalists that can affect the mindset, lifestyle, values and even ideology of the reader and one of them with the lexical choices used. As stated by Maghavira (2017) even though the mass media is only reporting, but if the lexical choice, terms or symbols that conventionally has a certain meaning in the community; it will inevitably disturb the attention of the public. Viboonchart and Gampper (2014) also explained that the use of different words also means different meanings that the sender wants to encode in the text. For example, the use of the word "sustainable", which, when used by the chief executive officer of a major corporation has a meaning quite different from the one used by an environmentalist.

A study on ideology and lexical choice has been conducted by He and Zhou (2015) and Setiawan, et al. (2018). Their study found that the ideology of the newspaper through lexical choices have an impact on the content of the news even though the news reports are based on the same incident. Besides, lexical choices have an impact on the content of the news even though the news reports the same incident. However, as far as the researchers' knowledge, no previous studies have examined the ideology through linguistic representation, especially in Ambon's local newspaper. Based on the previous studies and the gap above, the researchers interested in conducting the study the ideology through linguistic representation contained in Ambon's newspaper, Siwalima.

This newspaper was chosen because it was one of the active and brave local newspapers in reporting the riots in Moluccas, where at that time the news about the riots was a sensitive thing to talk about because it could trigger a war between the two religions because at that time newspapers may be the only media that is easily accessible to Moluccas people because of the limitations of accessing television and other media. Based on the background of the study above, the problems of this study is how was the linguistic representation of Moluccas riots in Siwalima? The objectives of the study is to investigate the linguistic representation of Moluccas riots in Siwalima. This study also stimulates the readers to be more careful in responding to the news with critical thinking awareness in order to make them become wise readers. 


\section{THEORETICAL BASIS}

\section{History and Reality Underlying Riot in Moluccas}

Some people argue that religion as the cause of the Moluccas conflict, but now emerging several studies on the causes of the Moluccas conflict since January 1999, among others, as follows. Pieris (2004) in his book entitled "Tragedi MalukuSebuah Krisis Peradaban" stated that riots in the Moluccas started from an ordinary conflict between two people who happened to be different religions, and then became the trigger of another conflict. The presence of provocateurs who deliberately designed the conflict to continue with the burning of some houses and the action successfully provoked people who ignited their emotions then burned, looted and killed. He asserted that they did not actually know that the conflict has been designed in a political scenario by the authorities who have benefited from the conflict. Additionally, the role of mass media that did not explain facts or not by reality, unbalanced, and made more conflicts at that time. The mass media also seemed to be used by many other parties especially those who have the interest to attack other parties that are considered opponents while strengthening its position (Pieris, 2004 : 34). Waileruny (2011: 58) added that one of the causes of the riots in Moluccas was due to the fall of the Soeharto government in 1998 and to restore its heyday, the way in which it was done was to disrupt security stability by conducting conflicts in various regions. This was done so that the community would trust the Orde Baru's power more than the power of reform.

\section{SIWALIMA}

The Siwalima newspaper was first launched on October 25, 1999, when a conflict about religion struck the Moluccas at that time. Siwalima is one of the newspapers that are widely read by the people of Moluccas. Siwalima issued by PT Siwalima Mandiri Permission for Minister of Information Decree No. 2588SK/ MENPEN/ SIUPP/1999, July 25. 1999, founders: A Latuconsina, J Mahulette, A J Soplantila, Drs. Dj Tuasalma, Tuasikal, Agustinus Patty. S.E. Person in charge: AJ Soplantila; representative: Samuel E Huwae; editor in chief: Martin Langoday; company leader: Johanes M Ruban (Siwalima)

\section{Lexical Choices}

Semantics is a study of meaning. Parera (2004: 89) divides linguistic meaning into two: lexical meanings and grammatical meanings. In this present study, it focused on lexical meaning: denotation and connotation meaning. Denotation is the dictionary meaning or meaning according to the definition in the dictionary (Parera, 2004: 98). For example, Hornby (2000: 258) defines the word "communist (n) person who believes in or supports communism or the word Terrorist (n) aperson who takes part in terrorism" (Hornby, 2000: 1396). Based on Parera (2004), "connotation means meaning that has gained additional certain feelings, certain emotions, certain values, and certain stimuli that are varied and unexpected too" (Parera, 2004: 98). For example, the word reform (reformasi) has got a connotation that needs to be maintained for those who disagree with the New Order (Orde Baru) regime, while for the New Order defenders the word reform has the connotation of "something that is hated and removed". From the example, it can be said that connotation has positive and negative meanings, depending on personal experience.

\section{Ideology}

Some classical theories about ideology include saying that group domination builds ideology in order to produce and legitimize their dominance. Darma (2014: 90) added in this perspective, ideology is social. Although it is social, it is used in- 
ternally among members of groups or communities. Ideology can form a group identity that can be distinguished from other groups. For example, in producing news texts, it can be analyzed whether the text contains certain ideology, whether feminism, capitalism, racism or socialism.

\section{Critical Discourse Analysis}

Fairclough offers a three-dimensional model representing three domains that must be analyzed, i.e. texts (sayings, writings, visual images, or combinations of all three), discourse practices that include the production and consumption of texts, and social practices (sociocultural practice). The first dimension, i.e. the text must be analyzed through a linguistic approach that includes formal forms such as vocabulary, grammar, and textual structure. The second type of analysis is the interpretation used to analyze the process, which is to interpret the text itself and how the text is consumed and interpreted by the reader. The third stage of analysis after interpretation is an explanation oriented to describe discourse as part of social practice and show the determination of discourse on social structure (Fairclough, 1995).

\section{RESEARCH METHOD}

This study used a qualitative method with Fairclough's (1995) model of Critical Discourse Analysis to help on the process of data analysis. Maghavira (2017) describes qualitative research as descriptive research and tends to use analysis with an inductive approach. The inductive approach itself observes first, and then draws conclusions based on that perspective. Moreover, the theoretical foundation was used as a guide so that the research focus was in accordance with the facts in the field.

The data for this study were linguistic representation of Moluccas riots, information related to Siwalima and social condition of Moluccas in 2000--2002. The researcher used the news articles from Ambon's local newspaper Siwalima, the official documents of Siwalima, books and historical records related to the riots as the data source. There were four different news related to the riots: (1) "Isak Tangis Perempuan GMP Soya di Reruntuban Gereja Tua" on May 11 2002 Edition: 131/V years III, (2) "Tak Tegas, Penanganan Kasus Maluku" on May $5^{\text {th }} 2000$ Edition: 154/V year I, (3) "Basudara Muslim yang Tolong Katong" on May $11^{\text {th }} 2000$ Edition: 159/V year I, and the last (4) "UKIM Pertanyakan Daya Deteksi Intelijen" on May $5^{\text {th }} 2000$ Edition: 154/V year I. The researchers got those newspapers and books from Badan Perpustakaan dan Arsip Daerah Provinsi Maluku (Moluccas' library). While the information about Siwalima, the researchers got from Siwalima office and internet. The researchers determend the articles as the data source, then the researchers used two stages of coding by Miles and Huberman (2014). After that, the researchers classified the data into a smaller number of categories: event, people and motives. In this study, the researcher used Fairclough's (1995) three-dimensional framework: text analysis, discursive practice, and sociocultural practice this study applied. Because the articles used Ambonese then, the researcher used Kamus Bahasa Melayu Ambon, Kamus Besar Bahasa Indonesia (Online KBBI), and Oxford Dictionary as the main reference to give the meaning of the words.

\section{DISCUSSION}

\section{The Linguistic Representation of Moluccas Riots in Siwalima}

\section{Text Analysis}

Text analysis is the first dimension of discourse by Fairclough (1995). The data that has been obtained classified into three categories: 
event, people and motives. This study found that from those 3 categories, there were 4 linguistic representations and 16 lexical choices of Moluccas riots in Siwalima. This study found 12 lexical choices which had negative meanings and only 4 lexical choices that had positive meanings.

\section{a. Event}

The Events were represented in Siwalima as a gloomy event. This can be seen from the lexical choices that are used to represent gloom during the riots. There are 4 lexical choices representing the event.

\section{- Datum source 3}

“... merupakan konflik vertikal."

The words konflik and vertikal are the imitated words from English "conflict" and "vertical". According to Hornby (2000: 272) "conflict” (n) means "a situation in which people, groups, or countries are involved in a serious disagreement". Meanwhile, "vertical" means "(of a line, pole, etc.) going straight up or down a level surface or from up to bottom in pictures" (2000: 1499).

Vertical conflict meant to conflict between the government and the people of Moluccas. This is because the word "vertical" means the line from top to bottom or vice versa. "Top" can be interpreted as the government while "bottom" can be interpreted as the people of Moluccas. Riots in Moluccas is always considered as a conflict between Christians and Muslims, Siwalima describes the conflict that occurred in Moluccas were not a conflict between the two groups, but between the government and the people of Moluccas.

\section{- Datum source 1}

"Perayaan HUT ke 34 perempuan GPM Soya berlangsung dalam situasi duka lara"

In line with KBBI V duka (adj.) means sad, while lara (adj.) also means "sad or pain". The combination these words duka lara mean "grief, sorrow, painful." Using duka lara, Siwalima wants to emphasize that the anniversary celebration was truly in sadness. This happened because at that time there was an attack which resulted to celebrate the anniversary with a situation of unhappiness.

\section{- Datum source 3}

"Mencermati realita konflik sosial kemasyarakatan di Maluku bingga kini, terus berada dalam suasana ketidakpastian"

In $\mathrm{KBBI} \mathrm{V}$, there is no literal explanation about ketidakpastian. Along with Hornby ketidakpastian (uncertainty (n)) means "something that you cannot be sure about" (2000: 1464). Siwalima describes the situation in Moluccas in the "gray area" or it could be said that at that time the conflict that occurred had not yet been resolved and neither the government nor the military did they duty in peace in Moluccas, but made the native Moluccas a victim instead.

\section{Datum source 2}

"Kasib basudara tak akan pernah lenyap, meski dibabat para leader-leader politik dengan segala wacana politiknya"

In line with The Lexicon (2013) babat (v) means "cut away" (p.19) addressed to political leaders, who were described as people who made Ambonese more hostile and almost lost love among themselves. The word dibabat has the meaning of a negative connotation, where the word babat can also mean removing (affection). Siwalima describes political leaders as provocateurs who have their own interests in the conflict.

\section{b. People}

The people were represented in two objects: Military and Moluccan. In representing the military, Siwalima used lexical choices which have negative denotation and connotation meaning while in representing Moluccan, they used positive denotation meaning. 


\section{- Datum source 1}

"...atas aksi biadab para teroris

berloreng yang mengkhoyak negeri Soya Minggu subuh 28 April lalu"

aksi (n) means "action, a movement, or attitude", biadab (adj.) means "do not know custom (manners), or impudent". Aksi biadab means "an action that savage, cruel and without mercy" (KBBI V), while "teroris" ( $\mathrm{n}$ ) is the imitated word from English, "terrorist." Hornby (2000: 1233) defines "terrorist" (n) "a person who takes part in terrorism". "Terrorist" is synonymous with "freedom fighter" (n) means "a name used to describe a person who uses violence to try removing a government from power." berloreng (adj) has connotation meaning with "army or soldier."

Moluccas identified berloreng with the army (TNI), because the design/pattern of their clothes had striped, para teroris berloreng may refers to army (TNI). Using aksi biadab para teroris berloreng, explicitly, Siwalima describes army negatively with lexical choices biadab which has a negative connotation meaning. This was because; at the time the armies were considered not neutral in handling the conflict and have their own agenda.

\section{- Datum source 4}

"Namun kenyataan konkrit di lapangan justru menimbulkan ketidak-becusan dalam memainkan perannya untuk menditeksi perkembangan situasi dari waktu ke waktu"

Ketidak-becusan has a synonym with ketidakmampuan which means "a state of inability or not strong” (KBBI V). Whereas Hornby (2000: 678) defines ketidakmampuan (incompetence (n)) means "the lack of skill or ability to do your job or a task as it should be done". Ketidak-becusan refers to the military which was unable to handle the conflicts that occur, even though those equipped with sophisticated weapons and trained to maintain the peace of a country were even con- sidered incompetent in handling the riots.

\section{- Datum source 3}

'Demikian juga penanganan aparat baik sipil maupun militer, sejak 19 Januari 1999 bingga sekarang ini berlangsung tidak efektif'

There is no literal explanation about tidake efektif in KBBI, while Hornby (2000: 693) defines tidak efektif (ineffective (adj) "(in doing something) not achieving what you want to achieve; not having any effect." Siwalima describes civil and military apparatus in handling riots that had no effect. So that riots still occur even though both the police and the army have handled it.

\section{Datum source 4}

"ditemukan tindakan keberpihakan aparat, yang umumnya membacking kelompok. penyerang"

The word keberpibakan is not literally explained in KBBI, while the Hornby (2000: 962) describes keberpibakan (partisan (n)) "a person who strongly supports a particular leader, group or idea". The military described by Siwalima is not neutral in handling conflicts in Moluccas and is more defending the attacking party.

\section{- Datum source 1}

"Tampak para perempuan GPM tak kuasa menahan air matanya..."

In KBBI V menahan (v) means "suffer, bear something (emotion, duty, etc.). While air mata means "water that melts from the eye (when crying, etc.)". Air mata also has two connotative meanings, both positive and negative. In this news article "air mata" has a negative meaning because of the GPM women who suffered because of the riots., Siwalima describes women GPM Soya (Moluccan) as victims.

\section{Datum source 2}

"Yang terpenting dari musibah Masnait adalah munculnya sebuah aksi pertobatan 
bahtin atau "rekonsiliasi" dari warga Muslim Tial"

Rekonsiliasi (n) is the imitated word from English, "reconciliation". Based on Hornby, it means "an end to a disagreement and start of a good relationship again." Reconciliation is aimed at Tial Muslims, where they helped victims of Christian ships. Siwalima described Tial residents as helpful people who wanted to end the war and build good relations between Muslims and Christians.

\section{- Datum source 2}

"Kasib damai masih utuh dikalangan rakyat kecil"

Masib (adv.) means currently in an unfinished or ongoing state. utuh (adj) (in circumstances) perfect as it is or as it was (not changed, not broken, not reduced and so on)" (KKBI V). In other words, masib utuh means that it is still awake and still there. This was shown to Ambonese who still loves one another even though there were still many people who also use religion to fight each other.

\section{- Datum source 2}

"Sekalipun katorang bermusuban, saling membunuh, tapi kasih sayang basudara belum bilang total"

Kasih sayang (adj.) means "with love or great care" (online Oxford Dictionary). While, basudara (adj.) is Ambonese, means "being relatives" (The Lexicon, 2013: 31). It related to family, kasih sayang basudara means to love each other fellow brothers. This is addressed to the native Moluccas, especially to the two hostile groups. Sinalima describes that they love one another explicitly.

\section{- Datum source 2}

"Mereka tolong dengan penuh kasih, penuh sayang"

Penub kasib (adj.) and penub sayang (adj.) have same meaning, which means "with love or great care" (online Oxford Dictionary). By using word choices that have same meaning, Siwalima that Muslims are very caring and love Christians who are in need of help.

\section{Datum source 2}

"Namun dirinya sendiri bagaimana rasa kemanusiaan yang cukup tinggi diperlihatkan oleh warga desa Tial yang menolongnya"

Rasa kemanusian (n) (humanity) means "the quality of being kind to people and animals by making sure that they do not suffer more than is necessary" (Hornby, 2000: 664). While cukup tinggi means "high" and it is synonymous with "big". Rasa kemanusiaan yang cukup tinggi means a high sense of caring for people or animals. Siwalima explicitly describes Muslims as people who care about each other.

\section{c. Motives}

The motives were represented in Siwalima as ideological motives and represented in negative meaning. This can be seen from the lexical choices used.

\section{- Datum source 2}

"tanpa mengikutsertakan sikap-sikap

fanatisme agama yang masib kita temukan pada leader-leader politike dan leader agama di kota ini"

Fanatisme (n) is the imitated word from English, "fanaticism" means (disapproving) extreme beliefs or behavior, especially in connection with religion or politics" (Hornby, 2000: 478). Fanaticism usually identified with things that are negative. While agama means "teachings, system that govern the system of faith (trust) and worship to the omnipotent God and rules of conduct that relate to human and human relation and their environment" (KBBI V). Religious fanaticism means excessive trust in the religion adhered to and more concerned with the group than the common interest. This usually refers to negative things. 
Siwalima described religious fanaticism as being offered to political leaders and religious leaders in Ambon who at that time still used religion as an excuse to remain hostile, even though the people had helped each other without their religious fanaticism.

\section{- Datum source 2}

"Musibab itu pun, agaknya merupakan teguran keras bagi warga Kota Ambon yang sudah tawar kasih damainya, untuk lebih serius mewujudkan perdamaian"

Along with KBBI V, tawar (adj.) means "tasteless", kasih sayang means "feeling affection". It is synonymous with "compassion." While damai (n) means "circumstances where it is not hostile." The use of "tawar kasih sayang damainya" means show less feeling or displaying a complete lack of feeling. It refers to Ambonese. In other word, it can be said that Ambonese do not care about what happened in Moluccas. Explicitly, Siwalima describes Ambonese as heartless people.

\section{- Datum source 2}

\section{"Tapi kenapa mereka begitu susah untuk berdamai"}

"Susab (adj.) means feeling unhappy about something." This refers to Ambonese. It is stated that "but why are they so hard to make peace." Implicitly, Siwalima describes Ambonese as a stubborn, because they are stubborn to make peace, even though the situation did not provide benefits for them.

\section{Discursive Practice}

Previous findings found that the event was represented in Siwalima as a gloomy event; this can be seen from the lexical choices used. The people were represented in two objects: military and Moluccan. In representing the military, Siwalima used lexical choices which have negative denotation and connotation meaning, while
Moluccan was represented in positive meanings. Also, the ideological motives were represented in negative meaning.

On this stage, the researcher analyzed using Fairclough's (1995) second dimension discourse practice, where this dimension relates to the production and consumption process of the text. The news of Moluccas riots was used by the researchers. The researchers examined it related to the text itself and the history behind the text.

First, based on the text itself related to the purpose of the text, the relationship between the text and who was involved. The purpose of the text was to criticize the government related to handling the riots in Moluccas. In delivering news, Siwalima described the riots that occurred during and after the riots in Moluccas in 2000--2002. Siwalima known as a newspaper that was quite active in giving criticism, related to conflict resolution. This can be seen from the four news contents which contain more criticism, especially to the government and military at that time and for Moluccan, they highlight more as victims and helpers. The informants of the news came from several professions ranging from a priest, ship's crew, and chairmen of the campus senate, where the content of the news varies, but it still appears that Siwalima emphasizes resolving conflicts that had not been resolved by the government.

Second, it is based on the history behind the text related to the history of Siwalima. At that time the mass media was considered to have favored only one particular group. As a result, Christians read certain newspapers, and vice versa, Muslims read certain newspapers. For this reason, Siwalima was first published on October 25, 1995, ten months after the SARA conflict was occurring on Moluccas. It has the motto "Unity and Brotherhood". As a press institution, Siwalima believed that they must play their part to help resolved the conflict. 
In addition, founders of Siwalima had different professions, religions and educational backgrounds, but it had the same goal of "resolving the Ambon conflict". The founders of Siwalima were A. Latuconsina is a Muslim with a law degree and worked as a lawyer; J. Mahulette is a Christian who worked in the government; A. J. Soplantila is a Christian who worked as a pastor; A. Patty is an economic and a Christian, while Tuasikal was a Muslim notary. There were at least fifteen thousand newspapers distributed every day during the conflict, both to Muslims and to Christians.

Based on the explanation, the researchers merged the text itself and the historical side of Siwalima. Yet, even though they came from a different background, but if seen, the founders of Siwalima are native Moluccan who may have been fed up with unbridled and protracted riots.

Moreover, Siwalima which was formed as an objective to carry out supervision, criticism, correction and facilities on matters relating to the public interest, as well as fighting for the values of justice and justice, highlighting the performance of the government and military (TNI/ POLRI) unable to resolve conflicts even involved in letting the conflict continue.

\section{Social-Cultural Practice}

The third dimension is social-cultural practice analysis based on the opinion that the social context that exists outside the media actually influences how the discourse is in the media. Editorial rooms or journalists are not sterile fields or empty spaces, but they are also determined by factors outside the media itself.

The linguistic representations of the riots by Siwalima were inseparable from the situation that occurred in Moluccas at that time, where the riots had destroyed Moluccas. They felt frightened by the ongoing conflict, both Christians and Muslims were anxious about the situation at that time. This was compounded by the government's inability and partiality of the military (TNI/POLRI) felt by the Moluccan in handling the riots (Waileruny, 2011).

Pieris (2004: 268) highlights some of the involvement in riots in Moluccas, among others: buying and selling weapons and ammunition, participating in provoking the masses, participating in training rioters, taking in information about the conditions and abilities of warring groups, and provoking mass emotions by shooting.

Even if it is considered that the involvement of the TNI and POLRI is not planned and systematic involvement in increasing conflict, in reality fail to control the situation and fail to act neutral is sufficient evidence that the TNI and POLRI play a role in perpetuating conflict and riots in Moluccas.

To sum up, the linguistic representation which was mostly in the form of criticism especially towards the government and the military at that time. When viewed from the background of the founder of Siwalima who are all native Moluccan and experienced the riots themselves, it can be said that it is the reason why the situation represented as a gloomy event. From this explanation, it can be concluded that Siwalima, in reporting on the Moluccas riots, was influenced by their own ideology. This is in line with Darma (2014: 90) who stated that ideology is not understood as something that exists in the individual itself but is accepted from the community where he lives, social position and so on. Linguistic representation is not only by institutional factors but also social conditions at the time. The riots that occurred 1999-2002 made Moluccas citizens frightened during their daily activities. 


\section{CLOSING}

The linguistic representations of Moluccas riots were represented in Siwalima as a gloomy event; the people were represented in two objects: military and Moluccan. In representing the military, Siwalima used lexical choices which have negative denotation and connotation meaning, while Moluccan was represented in a positive meaning. Also, the ideological motives were represented in negative meanings.

\section{BIBLIOGRAPHY}

Darma, Y. A. (2014). Analisis Wacana Kritis dalam Multiperspektife. Bandung: Refika Aditama.

Fairclough, N. (1995). Critical Discourse Analysis: The Critical Study of Language. Singapore: Longman Singapore Publisher.

Goss, J. (2000). "Understanding the "Maluku Wars": Overview of Sources of Comunal Conflict and Prospect for Peace". Cakalele, Vol. 11, pp. 7-37.

He, X \& Zhou, X. (2015). “Contractive Analysis of Lexical Choices and Ideologies in News Reporting the Same Accidents between Chinese and American Newspaper". Theory and Practice in Language Studie. Vol. 5, No. 11, pp. 2356-2365.

Hornby, A. S. (2000). Oxford Advance Learner's Dictionary of Current English. Sixth Edition. London: Oxford University Press.
Maghavira, G. (2017). "Analisis Wacana Kritis Pada Pemberitaan TEMPO.CO Tentang Kematian Taruna STIP Jakarta". Journal The Messenger. Vol. 9. No. 2.

Miles, M., Huberman, et al. (2014). Qualitative Data Analysis, A Methods Sourcebook Edition 3. United States of America: SAGE Publications, Inc.

Parera, J. D. (2004). Teori Semantik. Jakarta: Erlangga.

Pieris, J. (2004). Tragedi Maluku. Sebuah Krisis Perabadan. Jakarta: Buku Obor.

Setiawan, K. A., Chojimah, N., \& Khasanah, I. (2018). "Positive-self and negative-other representation in the online news Behind Indonesia's Anti-Chinese Riots and Indonesia Turns Its Chinese into Scapegoats". Alphabet, 01(01), 57-68. Doi:10.21776/ ub.alphabet.2018.01.01.07

Sholeh, B., (2008). "Conflict, Jihad, and Religious Identity in Maluku Eastern Indonesia". AlJami'ah. Vol. 46. No.1.

Viboonchart, N \& Gampper, C. (2014). “The Underlying Ideologies in News Article: The Study though the Use of Direct Quotations and Lexical Choices in an English Newspaper in Thailand and an American Newspaper". Canadian Center of Science and Education. Vol. 10, No.15

Waileruny, S. (2011). Membongkar Konspirasi di Balik Konflik Maluku. Jakarta: Obor. 